Egyptian J. of Nutrition Vol. XXXIII No. 1 (2018)

\title{
Effect of Red Beetroot Juice on Body Weight Status of Obese Anemic Rats
}

\author{
Hanan M. El-Ghandour, Eman M. Ragheb, \\ Agriculture Research Center, Regional Center for Food and \\ Feed, Giza, Egypt.
}

\begin{abstract}
The aim of this work is to investigate the ability of ingestion two different doses ( $1 \mathrm{ml}$ and $2 \mathrm{ml} / \mathrm{kg} / \mathrm{BW}$ ) of fresh red beetroot juice to improve anemia and its effect on final body weight of obese anemic rats. Forty two adult male Sprague- Dawley rats were fed on standard diet for one week for adaptation. Rats were then randomly divided into seven groups (6rats each) as follow: the first group was fed on basal diet only and served as control negative group, while groups $(2: 4)$ of rats $(n=18)$ were fed on high fat diet for four weeks to induce obesity, then continuously fed on high fat diet, deficient in iron and supplemented with (10 $\mathrm{g}$ tannic acid/kg diet) for further 3 weeks to induce anemia. These rats were then divided into three groups, positive control group and two other groups given orally $1 \mathrm{ml}$ and $2 \mathrm{ml}$ juice $/ \mathrm{kg}$ BW respectively. Groups (5:7) of rats $(n=18)$ were fed on basal diet, deficient in iron and supplemented with $(10 \mathrm{~g}$ tannic $\mathrm{acid} / \mathrm{kg}$ diet) for 3 weeks to induce anemia, then were divided into three groups, one positive control group (anemic) and two other groups given orally $1 \mathrm{ml}$ and $2 \mathrm{ml} / \mathrm{kg}$ BW fresh juice red beetroot respectively. The results showed that oral ingestion fresh beetroot juice $(1 \mathrm{ml}$ and $2 \mathrm{ml} / \mathrm{kg}$. BW $)$ significantly $(P<0.05)$ decreased the final
\end{abstract}




\section{Hanan M. EI-Ghandour, Eman M. Ragheb,}

body weight and body weight gain of anemic obese rats, and the weight reduction was $30.25,39.00 \%$ respectively due to ingestion fresh red beet juice that rich in (iron $15.34 \mathrm{mg} / 100 \mathrm{ml}$ juice). Fresh beetroot juice supplementation decreased significantly $(P<0.05)$ leptin concentrations, Moreover, hemoglobin, hematocrit and red blood cell concentration as well lipid profile and liver function were improved significantly compared to positive control group. The study recommends that obese patients suffering from anemia should drink fresh red beetroot juice.

\section{Introduction}

Overweight and obesity affected $1.6 \%$ of $2-6$ years old, $4.9 \%$ of $6-10$ years old, $14.7 \%$ of $10-14$ years old and $13.4 \%$ of $14-18$ years old of children in Egypt (Galal, 2002). In a report from the Egyptian National Nutrition Institute, (2004), there is increasing prevalence of obesity among children and adolescents reaching $5.8 \%$ among males and $9.7 \%$ among females. The global prevalence of obesity is increasing rapidly among adults as well as among children and adolescents in places where high dietary fat intake is a major risk factor for the development of obesity (Canbakan, et al., 2008). World Health Organization (WHO, 2014) reported that more than 1.9 billion adults (38\% of men and $40 \%$ of women) 18 years and older were overweight, and over 600 million were obese. The WHO estimated by the end 2015, 2.3 billion adults would be overweight and more than700 million obese (McArdle, et al., 2013).The Global School-based Student Health Survey conducted in seven African countries ( $n=23496$, with 11-17 years old) indicated that, unadjusted rates being underweight varied from $12.6 \%$ (Egypt) to $31.9 \%$ (Djibouti), while being overweight ranged from $8.7 \%$ (Ghana) to 


\section{Egyptian J. of Nutrition Vol. XXXIII No. 1 (2018)}

$31.4 \%$ (Egypt). Obesity rates ranged from $0.6 \%$ (Benin) to $9.3 \%$ (Egypt) (Manyanga, et al., 2014).

Obesity has become a serious problem that increases health costs and reduces healthy life years (Aronne, 2001 and Carnethon, et al., 2004). In addition, there is a strong association between obesity and the development of co morbid conditions, including insulin resistance and/or type 2 diabetes mellitus, hypertension, dyslipidemia and metabolic syndrome (Wilson, et al., 2005).Hence, obesity has become a leading global public health problem, and termed, as the millennium disease with worldwide spread (WHO, 2012).

Iron deficiency anemia (IDA) is the most prevalent nutritional deficiency worldwide. It is a major public health problem with adverse consequences, and affects over 2 billion people mainly young women and children (McLean, et al., 2009). Furthermore, iron uptake from the duodenum is limited in obese compared to normal weight children (Sanad, et al., 2011).Elevated body mass index and insulin resistance are associated with lower iron $(\mathrm{Fe})$ and $\mathrm{Hb}$ levels. These findings may be explained by the chronic inflammation of obesity and may contribute to obesity-related co-morbidities (Altunoğlu, et al., 2014).

Now, there is an increased demand for using plants in therapy "back to nature" instead of using synthetic drugs which may have adverse effects. Traditional medicinal plants are often cheaper, locally available, and easily consumable as raw or as simple medicinal preparations. These plants often mediate beneficial responses due to their active chemical constituents (Bogusz, et al., 2002 and Amin and Nagy, 2009). Red beetroot (Beta vulgaris L.) is a 


\section{Hanan M. EI-Ghandour, Eman M. Ragheb,}

vegetable characteristic of the Eastern and Central European diet, and is also used as a popular folk remedy for liver and kidney diseases, for stimulation of the immune and hematopoietic systems, and as a special diet in the treatment of cancer (Kapadia, et al., 2003).Today, beetroot is grown in many countries worldwide, is regularly consumed as part of the normal diet, and commonly used in manufacturing as a food colouring agent known as E162 (Georgiev, et al.,2010).Kujala, et al., (2002) and Wootton-Beard and Ryan, (2011) reported that beetroot is a rich source of phytochemical compounds that includes ascorbic acid, carotenoids, phenolic acids and flavonoids.

The aim of the present work was to investigate the ability of ingestion two different doses $(1 \mathrm{ml}$ and $2 \mathrm{ml} / \mathrm{kg} / \mathrm{BW}$ ) of fresh red beetroot juice to improve anemia and its effect on body weight status of obese anemic rats.

\section{Materials and Methods}

\section{Materials:-}

Casein, vitamins, minerals, cellulose, starch, tannic acid were purchased from local distributer of (Sigma Chemical Co) Cairo, Egypt. Red beetroot (Beta vulgaris L.) was purchased from a local market. Beef tallow was obtained from local market. Adult male albino rats (Sprague- Dawley strain) ( $\mathrm{n}=42$ rat) weighting approximately (190 $\pm 5 \mathrm{~g}$.) were purchased from Helwan Experimental Animals Farm. Kits for blood analysis was purchased from Gamma Trade Company, Dokki, Cairo, Egypt. 


\section{Egyptian J. of Nutrition Vol. XXXIII No. 1 (2018)}

\section{Methods:-}

A. Chemical composition: vitamin $\mathrm{C}$, iron and total fibers in fresh red beetroot juice were determined according to the official methods (A.O.A.O., 2006).

$B$. Induction of obesity: Rats were fed four weeks on basal diet according to (Reeves, et al., 1993) with some modification in fat content containing: casein $14 \%$, cellulose $5 \%$, vitamin mixture $1 \%$, mineral mixture $3.5 \%$, sucrose $10 \%$, (beef tallow $19 \%+$ soybean oil $1 \%$ ), I-cystine 0.18 , choline bitartrate $0.25 \%$ and the remainder is starch to induce obesity in rats (Liu, et al., 2004).

$\boldsymbol{C}$. Induction of anemia: Obese rats $(\mathrm{n}=18)$ were continuously fed on high fat diet supplemented with (10 g tannic acid/ $\mathrm{kg}$ diet) for 3 weeks (Afsana et al., 2004) at the same time, iron has been removed from the mineral mixture to induce anemia. Normal rats $(n=18)$ were fed on basal diet supplemented with tannic acid for 3 weeks to induce anemia according to (Afsanaet al., 2004).Blood samples were obtained after 3 weeks from tail vein to determine hemoglobin $(\mathrm{Hb})$ concentration. The hemoglobin concentration in normal rats was reported to be $(13.53 \pm 0.58 \mathrm{~g} / \mathrm{dl})$ which was used as the reference range (Wolford, et al., 1986).

D. Preparation of fresh red beetroot juice: Red beetroots were washed thoroughly in tap water and homogenized with a household blender. The juice was collected using suction filtration through filter papers, then stored at $-20^{\circ} \mathrm{C}$ for chemical analyses and biological experiment.

E. Biological study: Forty two adult male Sprague-Dawley rats were fed on standard diet for one week for adaptation. Rats were then randomly divided into seven groups (6rats each) as follow: group one was fed on basal diet only and kept as control negative group, while groups $(2,3,4)$ of rats $(n=18)$ were fed on high fat diet for four weeks to induce obesity, then continuously 


\section{Hanan M. EI-Ghandour, Eman M. Ragheb,}

fed on high fat diet, deficient in iron and supplemented with $(10 \mathrm{~g}$ tannic acid $/ \mathrm{kg}$ diet) for further 3 weeks to induce anemia. These rats were then divided into three groups, positive control group and two other groups given orally $1 \mathrm{ml}$ and $2 \mathrm{ml}$ juice $/ \mathrm{kg}$ BW respectively. Groups $(5,6,7)$ of rats $(n=18)$ were fed on basal diet, deficient in iron and supplemented with $(10 \mathrm{~g}$ tannic acid $/ \mathrm{kg}$ diet) for 3 weeks to induce anemia, then were divided into three groups, one positive control group (anemic)and two other groups given orally $1 \mathrm{ml}$ and $2 \mathrm{ml} / \mathrm{kg}$ BW fresh juice red beetroot respectively.

At the end of the experimental period (6 weeks), rats were fasted over night before sacrificing, two blood samples were collected, the first sample was collected into a tube containing EDTA as anticoagulant and used for determination: red blood cell (RBC) count, $\mathrm{Hb}$ concentration and Hematocrit (Hct) percentage. These parameters were quantified by standard hematological assay analyzer. The second blood sample was collected into a centrifuge tube without any anticoagulant and centrifuged to obtain serum which was stored at $-20^{\circ} \mathrm{C}$ until used for subsequent analysis.

F. Chemical analysis: total red blood cell counts determined according to (Dacie and Lewis, 1991). Hematocrit and hemoglobin concentration (Alexander and Grifiths, 1993) were determined. Serum total cholesterol (TC) (Richmond, 1973), triglycerides (TG) (Wahlefeld, 1974), high density lipoprotein (HDL-c) (Albers et al., 1983) were determined. Meanwhile, low density lipoprotein (LDL-C) and very low density lipoprotein (VLDL-c) were calculated according to (Fridewald et al., 1972).Serum Aspartate amino transferase (AST) and alanine amino transferase (ALT) (Bergmeyer et al., 1978) were 


\section{Egyptian J. of Nutrition Vol. XXXIII No. 1 (2018)}

determined. Serum albumin was measured according to (Weissman et al., 1950). Leptin hormone was determined using enzyme-linked immune sorbent (ELISA) assay (Xiong et al., 2005).

G. Statistical Analysis:-The obtained results were analyzed according to SPSS program. ANOVA test was used to compare results among groups and $\mathrm{P}<0.05$ was considered to be significant (SPSS, 1989).

\section{Results}

The chemical composition of fresh red beetroot juice is shown in Table (1). The results showed that iron content was $16.88(\mathrm{mg})$, vitamin C content was $7.10(\mathrm{mg})$ and total fiber content was 1.56 (mg).

The effect of oral ingestion fresh beetroot juice at two levels on body weight and body weight gain\% of obese anemic rats are recorded in Table (2). The statistical analysis showed that the mean values of body weight, body weight gain \%, feed intake and feed efficiency ratio of positive anemic control group significantly $(P<0.05)$ increased, compared to the negative control group . Obese anemic rats treated with $(1 \mathrm{ml}$ and $2 \mathrm{ml})$ of fresh beetroot juice had significant $(\mathrm{P}<0.05)$ decrease in final body weight, BWG\%, FI, FER, compared to the positive group (obese anemic). The final body weight and BWG\% of obese anemic rats treated with $2 \mathrm{ml}$ of fresh beetroot juice were significantly $(\mathrm{P}<0.05)$ lower, compared to obese anemic rats treated with $1 \mathrm{ml}$ of fresh beetroot juice. While, had significant increase in FER compared to obese anemic rats treated with $1 \mathrm{ml}$ of fresh beetroot juice. Anemic rats treated with $(1 \mathrm{ml}, 2 \mathrm{ml})$ of fresh 


\section{Hanan M. EI-Ghandour, Eman M. Ragheb,}

beetroot juice had significant $(P<0.05)$ decrease in final body weight, BWG\% and FER, compared to the positive group (anemic rats). The statistical analysis showed that there were non-significant $(p<0.05)$ changes in FER between anemic rats treated with $2 \mathrm{mlof}$ fresh beetroot juice and the positive group (anemic rats).Moreover, anemic rats treated with $2 \mathrm{mlof}$ fresh beetroot juice caused significant $(\mathrm{P}<0.05)$ increase in FER, compared to obese anemic rats treated with $1 \mathrm{ml}$ of fresh beetroot juice. The highest decrease in the final body weight, BWG\% and FER was recorded by administration $2 \mathrm{ml}$ of fresh beetroot juice.

The effect of oral ingestion fresh beetroot juice at two levels on serum leptin concentrations of obese anemic rats are recorded in Table (3). Results illustrated that positive control group (obese anemic) had significant increase $(P<0.05)$ in leptin hormone concentrations, compared to the negative control group. While, obese anemic rats treated with different two levels of oral ingestion fresh beetroot juice significantly $(P<0.05)$ reduced the level of leptin hormone concentrations, compared to the positive control group (obese anemic).Moreover, anemic rats treated with $2 \mathrm{mlof}$ fresh beetroot juice caused significant $(\mathrm{P}<0.05)$ reduction of leptin hormone concentrations compared to obese anemic rats treated with $1 \mathrm{ml}$ of juice. The greatest decrease in leptin hormone concentrations was obtained by $2 \mathrm{ml}$ of fresh beetroot juice. Also, results showed that positive control group (anemic rats) had significant increase $(P<0.05)$ in leptin hormone, compared to the negative control group. While, anemic rats treated with different two levels of oral ingestion fresh beetroot juice significantly $(P<0.05)$ reduced the level of leptin hormone, compared to the positive control group (anemic rats).Moreover, anemic rats treated with $2 \mathrm{mlof}$ fresh beetroot juice caused significant $(P<0.05)$ decrease in leptin hormone, compared to 


\section{Egyptian J. of Nutrition Vol. XXXIII No. 1 (2018)}

anemic rats treated with $1 \mathrm{ml}$ of fresh beetroot juice. The greatest decrease in leptin hormone concentrations was obtained by $2 \mathrm{ml}$ of fresh beetroot juice.

The effect of oral ingestion fresh beetroot juice at two levels on RBC, HCT and $\mathrm{Hb}$ concentrations of obese anemic rats are recorded in Table (4). Results revealed that positive control group (obese anemic) had significant decrease $(\mathrm{P}<0.05)$ in RBC, HCT and $\mathrm{Hb}$ concentrations of obese anemic rats compared to the negative control group. Also, obese anemic rats treated with different two levels of oral ingestion fresh beetroot juice had significant increase $(\mathrm{P}<0.05)$ in RBC, HCT and $\mathrm{Hb}$ concentrations, compared to the positive control group (obese anemic). Moreover, obese anemic rats treated with $2 \mathrm{mlof}$ fresh beetroot juice caused significant $(P<0.05)$ increase in red blood cell parameters concentrations compared to obese anemic rats treated with $1 \mathrm{ml}$ of fresh beetroot juice. Administration with $2 \mathrm{ml}$ of fresh beetroot juice provided greatest increase in the red blood cell parameters concentrations. The statistical analysis showed that positive control group (anemic rats) significantly reduced $(\mathrm{P}<0.05)$ red blood cell parameters concentrations, compared to the negative control group. While, anemic rats treated with different two levels of oral ingestion fresh beetroot juice had significant increase $(P<0.05)$ in red blood cell parameters concentrations, compared to the positive control group (anemic rats).The greatest increase in the relative red blood cell parameters concentrations was obtained by ingestion $2 \mathrm{ml}$ of fresh beetroot juice.

Table (5) showed the effect of oral ingestion fresh beetroot juice at two levels on liver functions of anemic obese rats. Result indicated that the positive group (obese anemic) had a significant 


\section{Hanan M. EI-Ghandour, Eman M. Ragheb,}

increase $(P<0.05)$ in serum levels of AST and ALT but had a significant decrease in albumin compared to the negative group. Supplementation with different two levels of oral ingestion fresh beetroot juice caused significant decrease $(P<0.05)$ in serum levels of AST and ALT, and significant increase in serum albumin, compared to the positive control group (obese anemic). The best results of liver functions were recorded for obese anemic rats treated with $2 \mathrm{mlof}$ fresh beetroot.

Results indicated that anemic rats treated with different two levels of oral ingestion fresh beetroot juice had significant decrease $(P<0.05)$ in serum levels of AST and ALT as compared to the positive control group (anemic rats). While, serum level of albumin are significantly $(P<0.05)$ increased. Moreover, anemic rats treated with 2 mlof fresh beetroot juice caused significant $(P<0.05)$ decrease in serum levels of AST and ALT and caused significant increase in serum level of albumin compared to anemic rats treated with $1 \mathrm{ml}$ of fresh beetroot juice. The best results of liver functions recorded for anemic rats treated with $2 \mathrm{mlof}$ fresh beetroot.

Results in Table (6) indicated that obese anemic rats treated with different two levels of oral ingestion fresh beetroot juice had significant decrease $(P<0.05)$ in serum levels of $T C, T G, V L D L-C$, LDL-C and caused significant increase in serum HDL-C, as compared to the positive control group (obese anemic).Moreover, obese anemic rats treated with $2 \mathrm{mlof}$ fresh beetroot juice caused significant decrease in serum levels of TC, TG, VLDL-C and LDL-C caused but caused significant increase in serum level of HDL-c compared to obese anemic rats treated with $1 \mathrm{ml}$ of fresh beetroot juice. Results indicated that anemic rats treated with different two levels of oral ingestion fresh beetroot juice had significant decrease $(P<0.05)$ in 


\section{Egyptian J. of Nutrition Vol. XXXIII No. 1 (2018)}

serum levels of lipid profile as compared to the positive control group (anemic rats). While, anemic rats treated with different two levels of oral ingestion fresh beetroot juice had significant increase $(P<0.05)$ in serum level of HDL-c compared to the positive control group (anemic rats). Moreover, there were non-significant differences in serum levels of TC, TG, HDL-C, VLDL-C and LDL-c between two levels of fresh beetroot juice. The best results of lipid profile are recorded for anemic rats treated with 2 mlof fresh beetroot.

\section{Discussion}

Obesity and related complications as well as IDA are 2 major issues that affect significant proportions of the global population (Cheng et al., 2012). This is of considerable concern for the wellbeing of the population given that overweight and obese people are at increased risk for co-morbidities, functional decline, impaired quality of life, increased use of health care resources, and increased mortality. They are global epidemics affecting billions with regional disparities (Low, et al., 2009). The link between obesity and iron might be related to the increased expression of hepcidin from adipose tissue which could act as a negative regulator of intestinal iron absorption (Bekri, et al., 2006). Hepcidin production in obesity has been shown to be over expressed and correlated with low iron status (Yanoff, et al., 2007). Some investigators (Keaney et al., 2003) found an increase in oxidants and a decrease in the activities of the body's protective antioxidants in obese individuals.

The most common form of iron supplement is ferrous sulfate, but it is known to produce intestinal side effects such as constipation, nausea, and bloating in many users (Hansen, 1994).Therefore, nowadays there is an increased demand for using plants in therapy instead of using synthetic drugs. These plants often mediate 


\section{Hanan M. El-Ghandour, Eman M. Ragheb,}

beneficial responses due to their active chemical constituents (Bogusz, et al., 2002 and Amin and Nagy, 2009). Beetroot as a source of iron is grown in many countries worldwide, and can regularly be consumed as part of the normal diet(ZielińskaPrzyjemska, et al., 2009 and Georgiev, et al., 2010).

The results from the current work revealed that feeding rats with high fat and free iron diet with tannic acid supplementation for six weeks significantly increased the final body weight, compared to control negative group (table 2). These results are agreement with Winzell and Ahrén, (2004) who reported that, body weight was higher in mice fed the high-fat diet already after the first week, due to higher dietary intake in combination with lower metabolic efficiency.

The reduction in body weight of obese anemic rats might be related to higher concentrations of serum hemoglobin as seen in (table 4),this result was confirmed with that Menzie, et al., (2008) who found significantly lower levels of serum iron and transferrin saturation in obese people when compared to non-obese adult volunteers. Iron deficiency (ID) and anemia may lead to fatigue and thereby to an additional decrease in physical activity, further aggravating weight gain (Munoz, et al., 2009). Iron depletion might result from the increased iron requirement of obese people because of their larger blood volume and/or their consumption of energydense, nutrient-poor foods (Pinhas-Hamiel, et al., 2003). Hypoferremia may be the chronic inflammation seen in obesity (Yanoff, et al., 2007). Additionally, ID may impair mitochondrial respiratory chain activity, thereby limiting exercise capacity and augmenting insulin resistance (Manios, et al., 2013).

Another explanation about the relationship between anemia and obesity, severe iron deficiency may lower thyroid peroxidase activity and interfere with the synthesis of thyroid hormones (Hess, et 


\section{Egyptian J. of Nutrition Vol. XXXIII No. 1 (2018)}

al., 2002). Soliman, et al. (2010) found that tT3 and tT4 levels of anemic rats were significantly lower than normal control and tT3/tT4 ratio was significantly higher in group treated with $(40 \mathrm{mg}$ ferrous sulphate $/ \mathrm{kg}$ diet) than normal control group. It is well known that hypothyroidism (characterized by low thyroid hormones) causes a weight increase together with a decrease in basal metabolic rate and thermo genesis (Rotondi,et al., 2009).

The oral ingestion of fresh beetroot juice significantly improved the hematological parameters of anemic obese rats. The weight reduction may result from the constituents in red beetroot juice such as vitamin C (5.22 $\mathrm{mg})$, iron $(15.34 \mathrm{mg})$ and low dietary fiber content $(1.98 \mathrm{mg} / 100 \mathrm{ml}$ juice) as seen on table (1). Beetroot is a rich source of phytochemical compounds that includes ascorbic acid, carotenoids, phenolic acids and flavonoids (Georgiev, et al. 2010). It has been reported by Khoshnevisan, et al., (2004) that citrus fruits and fruits rich in vitamin $C$ improved iron status in iron depleted preschool children. In a study carried out by Siegenberg, et al., (1991), it was noted that ascorbic acid prevents the dose dependent inhibitory effect of tannic acid on non -heme iron absorption in man.

A higher risk of low concentrations of iron and vitamin $\mathrm{C}$ has been observed in obese children and adolescents compared to children and adolescents with normal weight (Aeberli, et al., 2009). The same results were reported by (García, et al., and 2013), vitamin $\mathrm{C}$ and vitamin $\mathrm{E}$ were negatively associated with $\mathrm{BMI}$, waistto-weight ratio and body abdominal fat.

Moretti, et al.,(2006) reported that, when considering the responsiveness to iron fortification, there was an inverse relationship between BMI Z-score and change in body iron. 


\section{Hanan M. EI-Ghandour, Eman M. Ragheb,}

Leptin is a hormone produced mainly by adipocytes, and is involved in controlling body weight by increasing both satiety and energy expenditure (Vigueras-Villaseñor et al., 2011). Leptin levels are excessively high in obese people as a result of leptin resistance, which is associated with weight gain. The results in the present study revealed that, the anemic obese rats showed significant increase $(P<0.05)$ in leptin concentration.

Moreover, the current results illustrated that ingestion fresh juice of beetroot at different levels significantly reduced the level of leptin hormone concentration (table 3). Leptin concentration is related to the amount and distribution of body fat therefore, the higher the body weights, the higher the leptin concentration in human and rodents (Aizawa-Abe, et al., 2000). The reduction of leptin level might be related to vitamin $C$ content in juice of beetroot(5.22 $\mathrm{mg} / 100 \mathrm{ml}$ ). Feeding rats with vitamin $\mathrm{C}$ reduced the circulating levels of leptin and decreased body weight and adiposity in a rat model (Garcia-Diaz, et al., 2007). It has been observed that vitamin C intake is negatively associated with the occurrence of several conditions such asobesity, by modulate adipocyte lipolysis and inhibit leptin secretion on isolated adipocytes (Garcia-Diaz, et al., 2014).

The obtained results as seen in tables (4 and 5) illustrated that, obesity and anemia induced to rats caused a significant decrease $(\mathrm{P}<0.05)$ in hematological parameters (RBC, Hb, Hct and total iron) as compared to normal rats. Dambal, et al., (2011) found that the mean iron levels were significantly decreased in overweight and obese individuals than those in the control group $(P<0.001)$. Insufficient body stores of iron lead to a depleted RBC mass which, in turn, leads to a decreased hemoglobin concentration (hypochromia) and decreased oxygen-carrying capacity of the blood (Campos, et al., 1998). Both serum iron concentrations and iron 


\section{Egyptian J. of Nutrition Vol. XXXIII No. 1 (2018)}

stores, as indicated by serum ferritin concentrations, show a negative correlation with BMI (Pinhas-Hamiel, et al., 2003).

Anemia may be caused by a decrease in RBC production, or reduction in $\mathrm{Hb}$ content of the blood, or combination of these Priya, et al., (2013), these results were in the line with our results, in which tannic acid supplementation $10 \mathrm{~g} / \mathrm{kg}$ diet for $3 \mathrm{wks}$ and diet deficient in iron significantly decreased the hematological parameters. A further study found a strong link between ID and BMI across all races, ages and amounts of dietary intake (Tussing-Humphreys, et al., 2009).Obesity-associated inflammation is tightly linked to iron deficiency and involves impaired duodenal iron absorption associated with low expression of duodenal ferroportin along with elevated hepcidin concentrations (Aigner, et al., 2014).

As mentioned previously, oral ingestion fresh beetroot juice to anemic obese rats significantly increases $(P<0.05)$ the hematological parameters as compared with the positive control group. These results were in agreement with the finding of Priya, et al., (2013) who found that 60 adolescent girls of age 15-17 years showed a highly significant improvement in hemoglobin level following the ingestion of $(100 \mathrm{ml})$ beetroot juice for 20 day $(P<0.001)$. Moreover, the dietary intake of Vitamin $C$ along with iron rich sources enhances the absorption of iron significantly (Fishman, 2000).

The elevation of enzyme activities (ALT, AST and ALP) and altered levels of bilirubin and protein are due to increased production of free radicals, which initiate lipid peroxidation that leads to cellular damage (Pal, et al ., 2010).Lipid-rich diets are capable of generating ROS because they can alter oxygen metabolism. Upon the increase of adipose tissue, the activity of antioxidant enzymes was found to be significantly diminished. High ROS production and the decrease in antioxidant capacity lead to various abnormalities (Fernández- 


\section{Hanan M. EI-Ghandour, Eman M. Ragheb,}

Sánchez, et al., 2011).Investigations of red beetroot constituents focus on the betalains (red-violet betacyanins and yellow betaxanthins) (Kujala, et al., 2002). The most abundant betalain pigments in red beet juice were betanin, vulgaxanthin, is obetanin (Slavov, et al., 2013). A number of investigations have reported betalains to have high antioxidant and anti-inflammatory capabilities in vitro and a variety of in vivo animal models (Vulić, et al., 2014).

Overweight and obesity significantly affects liver function and may lead to further complications of the liver. Serum ALT best indicates liver dysfunction (Qureshi, et al., 2006), these results are in agreement with our study. The present results (table5) indicated that oral ingestion of fresh beetroot juice significantly improved liver functions. These results are in agreement with Sadeek, (2011) who reported that beetroot juice significantly $(P<0.05)$ restored the enzyme activities of the liver AST, ALT and ALP to normal level in the tested rats. Agarwal et al., (2006) and Pal, et al., (2010) reported a hepatoprotective activity of beetroot ethanolic extract against $\mathrm{CCl} 4$ induced liver injury in rats. Other reports indicate that Beta vulgaris extracts (root) possess anti-inflammatory and hepatoprotective activities (Kanner, et al., 2001), antihypertensive, hypoglycemic and antioxidant (Ninfali and Angelino, 2013).

Obese anemic rats had a significant increase $(P<0.05)$ in lipid profile as compared to control normal group (table 6 ). These results are in agreement with Novelli, et al., (2007)who reported that, the level of TG, CT and LDL-C were higher in rats receiving the control chow and drinking 30\% sucrose and fed a high-carbohydrate diet than in control negative group. But HDL-C decreased in rats fed a high-carbohydrate diet.German and Dillard, (2004) reported that, consumption of fat-rich diet directly affects the serum lipid profile and the fatty acids composition, which is an important factor in the 


\section{Egyptian J. of Nutrition Vol. XXXIII No. 1 (2018)}

modulation of lipid metabolism. The high saturated fatty acids intake increases LDL-c and reduces HDL-c in the bloodstream.

The results of current study demonstrated also that ingestion with fresh juice of beetroot at different levels significantly decreased $(P<0.05)$ the elevated lipid profile and significantly increased $(\mathrm{P}<.005)$ the level of HDL-C, compared to control negative group. These results were in agreement with the finding of (Sadeek, 2011) who mentioned that, oral ingestion of fresh red beetroot juice $(8 \mathrm{ml} / \mathrm{Kg} /$ day) significantly decreased $(P<0.05)$ serum $T C, T G, V L D L-$ $C$ and LDL-C and also a significant elevation $(P<0.05)$ occurred in the level of HDL-C. The intense red color of beetroots derives from high concentrations of betalains (Gandia-Herrero et al., 2010) that are widely used as antioxidant.Apart from betalains, small amounts of hydroxyl cinnamic acids such as gallic, syringic, and caffeic acids and flavonoids have been identified (Kazimierczak, et al., 2014). The benefits of betalains include the inhibition of lipid peroxidation (Reddy, et al., 2005), increased resistance to the oxidation of lowdensity lipoproteins (Tesoriere, et al., 2003).

Conclusion: it could be concluded that administration fresh red beetroot juice at two levels ( $1 \mathrm{ml}$ or $2 \mathrm{ml} / \mathrm{kg} / \mathrm{BW}$ ) to obese anemic rats has been treated anemia and decreased the final body weight of the obese anemic rats as well leptin concentrations was decreased with improving lipid profile and liver functions. So that, fresh red beetroot juice might be recommended for obese patients suffering from anemia. 


\section{Hanan M. El-Ghandour, Eman M. Ragheb,}

Table (1): Chemical composition of fresh red beetroot juice.

\begin{tabular}{c|c}
\hline Parameters & $\begin{array}{c}\text { Fresh beetroot juice }(\mathrm{mg} / 100 \\
\mathrm{ml})\end{array}$ \\
\hline Iron & 16.88 \\
\hline Vitamin C & 7.10 \\
\hline Total fiber & 1.56 \\
\hline
\end{tabular}

Table (2): Effect of oral ingestion fresh beetroot juice at two levels on body weight, BWG\% and FER of obese anemic rats.

\begin{tabular}{|c|c|c|c|c|c|}
\hline Groups & Initial BW (g) & Final BW (g) & BWG\% & $\begin{array}{c}\mathrm{FI} \\
(\mathrm{g} / \text { day/rat })\end{array}$ & FER \\
\hline Control (-ve) & $183.40 \pm 1.70^{b}$ & $219.76 \pm 2.82^{c}$ & $20.04 \pm 2.14^{c}$ & 15.33 & $2.37 \pm 0.23^{b}$ \\
\hline $\begin{array}{l}\text { Control }(+v e) \text { : } \\
\text { obese anemic }\end{array}$ & $206.53 \pm 1.44^{a}$ & $296.23 \pm 2.69^{a}$ & $43.46 \pm 2.28^{a}$ & 18.41 & $4.87 \pm 0.22^{a}$ \\
\hline $\begin{array}{l}\text { Obese anemic } \\
\text { rats }+1 \mathrm{ml} \text { juice } / \mathrm{kg}\end{array}$ & $209.56 \pm 1.28^{a}$ & $187.20 \pm 3.74^{d}$ & $-22.61 \pm 1.35^{d}$ & 16.22 & $1.37 \pm 0.15^{c}$ \\
\hline $\begin{array}{l}\text { Obese anemic rats } \\
+2 \mathrm{ml} \text { juice } / \mathrm{kg}\end{array}$ & $205.33 \pm 1.45^{a}$ & $169.60 \pm 0.83^{e}$ & $-29.57 \pm 0.51^{e}$ & 15.00 & $2.71 \pm 0.06^{b}$ \\
\hline $\begin{array}{l}\text { Control }(+\mathrm{ve}) \text { : } \\
\text { anemic rats }\end{array}$ & $205.67 \pm 1.85^{a}$ & $263.50 \pm 2.78^{b}$ & $28.16 \pm 2.50^{b}$ & 20.85 & $2.77 \pm 0.21^{b}$ \\
\hline $\begin{array}{l}\text { Anemic rats }+1 \mathrm{ml} \\
\text { juice } / \mathrm{kg}\end{array}$ & $204.96 \pm 1.54^{a}$ & $180.86 \pm 1.27^{d}$ & $-23.95 \pm 0.46^{d}$ & 17.64 & $1.36 \pm 0.06^{c}$ \\
\hline $\begin{array}{l}\text { Anemic rats }+2 \mathrm{ml} \\
\text { juice } / \mathrm{kg}\end{array}$ & $205.66 \pm 1.76^{a}$ & $164.9 \pm 1.59^{e}$ & $-31.97 \pm 0.42^{e}$ & 15.98 & $2.23 \pm 0.08^{b}$ \\
\hline
\end{tabular}

Values were expressed as Means \pm SE.

Values at the same column with different letters are significant at $\mathrm{P}<0.05$ 


\section{Egyptian J. of Nutrition Vol. XXXIII No. 1 (2018)}

Table (3): Effect of oralingestion fresh beetroot juice at two levels on serum leptin concentrations of obese anemic rats.

\begin{tabular}{|c|c|}
\hline $\begin{array}{ll}\text { Groups } & \text { Parameters } \\
\end{array}$ & Leptin $(\mu g / l)$ \\
\hline Control (-ve) & $8.87 \pm 0.17^{1}$ \\
\hline Control (+ve ): obese anemic & $26.84 \pm 1.02^{a}$ \\
\hline Obese anemic rats $+1 \mathrm{ml}$ juice $/ \mathrm{kg}$ & $19.60 \pm 0.61^{\mathrm{c}}$ \\
\hline Obese anemic rats $+2 \mathrm{ml}$ juice $/ \mathrm{kg}$ & $13.40 \pm 0.40^{\mathrm{e}}$ \\
\hline Control (+ve): anemic rats & $22.43 \pm 0.44^{b}$ \\
\hline Anemic rats $+1 \mathrm{ml}$ juice $/ \mathrm{kg}$ & $17.33 \pm 0.56^{\mathrm{d}}$ \\
\hline Anemic rats $+2 \mathrm{ml}$ juice $/ \mathrm{kg}$ & $12.30 \pm 0.78^{e}$ \\
\hline
\end{tabular}

Values were expressed as Means \pm SE.

Values at the same column with different letters are significant at $\mathrm{P}<0.05$.

Table (4): Effect of oral ingestion fresh beetroot juice at two levels on red blood cell parameters concentrations of obese anemic rats.

\begin{tabular}{l|l|l|l}
\hline $\begin{array}{l}\text { Parameters } \\
\text { Groups }\end{array}$ & \multicolumn{1}{|c|}{ RBC $\left(10^{6} / \mathrm{ml}\right)$} & $\mathrm{Hb}(\mathrm{g} / \mathrm{dl})$ & $\mathrm{Hct}(\%)$ \\
\hline Control (-ve) & $10.38 \pm 0.52^{\mathrm{a}}$ & $13.83 \pm 0.19^{\mathrm{a}}$ & $42.63 \pm 1.17^{\mathrm{a}}$ \\
\hline Control(+ve):obese anemic & $5.73 \pm 0.20^{\mathrm{d}}$ & $6.96 \pm 0.43^{\mathrm{r}}$ & $23.73 \pm 0.82^{\mathrm{e}}$ \\
\hline Obese anemic rats $+1 \mathrm{ml}$ juice $/ \mathrm{kg}$ & $6.90 \pm 0.14^{\mathrm{c}}$ & $10.32 \pm 0.30^{\mathrm{d}}$ & $33.34 \pm 0.81^{\mathrm{c}}$ \\
\hline Obese anemic rats $+2 \mathrm{ml}$ juice $/ \mathrm{kg}$ & $8.98 \pm 0.33^{\mathrm{b}}$ & $11.39 \pm 0.29 \mathrm{~b}^{\mathrm{c}}$ & $38.83 \pm 0.38^{\mathrm{b}}$ \\
\hline Control $(+\mathrm{ve}):$ anemic rats & $4.86 \pm 0.14^{\mathrm{d}}$ & $8.06 \pm 0.17^{\mathrm{e}}$ & $27.50 \pm 0.26^{\mathrm{d}}$ \\
\hline Anemic rats $+1 \mathrm{ml}$ juice $/ \mathrm{kg}$ & $8.36 \pm 0.14^{\mathrm{b}}$ & $11.13 \pm 0.35^{\mathrm{cd}}$ & $39.03 \pm 0.24^{\mathrm{b}}$ \\
\hline Anemic rats $+2 \mathrm{ml}$ juice $/ \mathrm{kg}$ & $10.45 \pm 0.33^{\mathrm{a}}$ & $12.13 \pm 0.14^{\mathrm{b}}$ & $40.53 \pm 0.37^{\mathrm{b}}$ \\
\hline
\end{tabular}

Values were expressed as Means \pm SE.

Values at the same column with different letters are significant at $\mathrm{P}<0.05$. 
Hanan M. EI-Ghandour, Eman M. Ragheb,

Table (5): Effect of oral ingestion fresh beetroot juice at two levels on liver functions of anemic obese rats.

\begin{tabular}{l|c|c|c}
\hline \multicolumn{1}{c|}{ Parameters } & ALT $(\mu / \mathrm{L})$ & AST $(\mu / L)$ & Albumin $(g / d)$ \\
\hline Groups & $36.53 \pm 0.48^{\mathrm{e}}$ & $68.50 \pm 0.86^{\mathrm{d}}$ & $7.63 \pm 0.21^{\mathrm{a}}$ \\
\hline $\begin{array}{l}\text { Control }(-\mathrm{ve}) \\
\begin{array}{l}\text { Control}(+\mathrm{ve}) \text { : obese } \\
\text { anemic }\end{array}\end{array}$ & $58.00 \pm 1.65^{\mathrm{a}}$ & $98.26 \pm 2.29^{\mathrm{a}}$ & $3.70 \pm 0.11^{\mathrm{e}}$ \\
\hline $\begin{array}{l}\text { Obese anemic } \\
\text { rats+ } 1 \mathrm{ml} \text { juice } / \mathrm{kg}\end{array}$ & $47.80 \pm 0.56^{\mathrm{c}}$ & $73.90 \pm 1.26^{\mathrm{c}}$ & $4.76 \pm 0.08^{\mathrm{d}}$ \\
\hline $\begin{array}{l}\text { Obese anemic rats } \\
+2 \mathrm{ml} \text { juice } / \mathrm{kg}\end{array}$ & $42.03 \pm 1.02^{\mathrm{d}}$ & $72.03 \pm 1.74^{\mathrm{cd}}$ & $5.83 \pm 0.12^{\mathrm{c}}$ \\
\hline $\begin{array}{l}\text { Control }(+\mathrm{ve}): \\
\text { anemic rats }\end{array}$ & $50.86 \pm 1.02^{\mathrm{b}}$ & $90.23 \pm 1.53^{\mathrm{b}}$ & $3.90 \pm 0.11^{\mathrm{e}}$ \\
\hline $\begin{array}{l}\text { Anemic rats }+1 \mathrm{ml} \\
\text { juice } / \mathrm{kg}\end{array}$ & $40.03 \pm 0.61^{\mathrm{d}}$ & $69.20 \pm 0.61^{\mathrm{cd}}$ & $5.80 \pm 0.15^{\mathrm{c}}$ \\
\hline $\begin{array}{l}\text { Anemic rats }+2 \mathrm{ml} \\
\text { juice } / \mathrm{kg}\end{array}$ & $37.23 \pm 0.39^{\mathrm{e}}$ & $62.10 \pm 1.47^{\mathrm{e}}$ & $6.83 \pm 0.12^{\mathrm{b}}$ \\
\hline
\end{tabular}

Values were expressed as Means \pm SE.

Values at the same column with different letters are significant at $\mathrm{P}<0.05$. 


\section{Egyptian J. of Nutrition Vol. XXXIII No. 1 (2018)}

Table (6): Effect of oral ingestion fresh beetroot juice at two levels on lipid profile of anemic obese rats.

\begin{tabular}{|c|c|c|c|c|c|}
\hline \multirow{2}{*}{ Groups } & $\mathrm{TC}$ & $\mathrm{TG}$ & HDL-C & VLDL-C & LDL-C \\
\hline & \multicolumn{5}{|c|}{$(\mathrm{mg} / \mathrm{dl})$} \\
\hline Control (-ve) & $94.33 \pm 1.45^{c}$ & $62.56 \pm 1.28^{c}$ & $64.53 \pm 1.07^{a}$ & $12.51 \pm 0.25^{c}$ & $17.28 \pm 2.69^{d}$ \\
\hline $\begin{array}{l}\text { Control(+ve):obese } \\
\text { anemic }\end{array}$ & $118.20 \pm 1.97^{a}$ & $96.16 \pm 2.94^{a}$ & $41.93 \pm 1.09^{d}$ & $19.23 \pm 0.58^{a}$ & $57.03 \pm 3.09^{\mathrm{a}}$ \\
\hline $\begin{array}{l}\text { Obese anemic } \\
\text { rats+ } 1 \mathrm{ml} \text { juice } / \mathrm{kg}\end{array}$ & $105.50 \pm 1.32^{b}$ & $77.93 \pm 1.31^{b}$ & $50.60 \pm 0.97^{c}$ & $15.58 \pm 0.26^{b}$ & $39.31 \pm 0.81^{c}$ \\
\hline $\begin{array}{l}\text { Obese anemic rats } \\
+2 \mathrm{ml} \text { juice } / \mathrm{kg}\end{array}$ & $90.46 \pm 1.34^{c}$ & $66.73 \pm 1.47^{c}$ & $57.46 \pm 1.27^{b}$ & $13.34 \pm 0.29^{c}$ & $19.65 \pm 2.33^{d}$ \\
\hline $\begin{array}{l}\text { Control }(+\mathrm{ve}) \text { : } \\
\text { anemic rats }\end{array}$ & $105.83 \pm 4.32^{b}$ & $76.23 \pm 1.90^{b}$ & $43.86 \pm 2.01^{d}$ & $15.24 \pm 0.38^{b}$ & $46.72 \pm 2.17^{b}$ \\
\hline $\begin{array}{l}\text { Anemic rats }+1 \mathrm{ml} \\
\text { juice } / \mathrm{kg}\end{array}$ & $90.33 \pm 2.02^{c}$ & $67.03 \pm 0.86^{c}$ & $56.66 \pm 0.88^{b}$ & $13.35 \pm 0.15^{c}$ & $20.31 \pm 1.54^{d}$ \\
\hline $\begin{array}{l}\text { Anemic rats }+2 \text { ml } \\
\text { juice } / \mathrm{kg}\end{array}$ & $87.56 \pm 1.66^{c}$ & $63.66 \pm 1.87^{c}$ & $60.26 \pm 0.93^{b}$ & $12.73 \pm 0.37^{c}$ & $14.56 \pm 0.81^{d}$ \\
\hline
\end{tabular}

Values were expressed as Means \pm SE.

Values at the same column with different letters are significant at $\mathrm{P}<0.05$. 
Hanan M. El-Ghandour, Eman M. Ragheb,

\section{References}

Aizawa-Abe M.; Ogawa Y.; Masuzaki H.; Ebinara K.; Satoh N. and et al., (2000):

Pathophysiological role of leptin in obesity-related hypertension. J. Clin. Invest., 105(9):1243-1252.

A.O.A.O., (2006):

Official Methods of Analysis. $18^{\text {th }}$ Ed. lean soft tissue mass: Differing relation to body cell Analytical Chemists, Washington DC. No. 935.13 and mass across the adult life span. Chapter 4, pp: 57-61.

Aeberli, I.; Hurrell, R.F. and Zimmermann, M.B. (2009):

Overweight children have higher circulating hepcidin concentrations and lower iron status but have dietary iron intakes and bioavailability comparable with normal weight children. Int. J. Obes. (Lond.), 33: 1111-1117.

Afsana, K.; Shiga, K.; Ishizuka, S. and Hara, H. (2004):

Reducing effect of Ingesting tannic acid on the absorption of iron but not of zinc, copper and manganese by rats. Biosci.Biotechnol.Biochem., 68(3):584-592.

Agarwal M.; Srivastava, V.K.; Saxena, K.K. and Kumar, A. (2006). Hepatoprotective activity of Beta vulgaris against $\mathrm{CCl} 4$-induced hepatic injury in rats. Fitoterapia, 77 (2): 91-93. 


\section{Egyptian J. of Nutrition Vol. XXXIII No. 1 (2018)}

Aigner E.; Feldman A. and Datz C. (2014):

Obesity as an Emerging Risk Factor for Iron Deficiency. Nutrients, 6:3587-3600.

Albers, N.; Benderson V. and Warnick G. (1983):

Enzymatic determination of high density lipoprotein cholesterol, Selected Methods, Clin. Chem., 10 :91-99.

Alexander R.R.; and Grifiths J.M. (1993):

Basic biochemical methods (2 ${ }^{\text {nd }}$ ed.) (pp 186-7). New York: Wiley-Liss.

Altunoğlu E.; Müderrisoğlu C.; Erdenen F.; Ülgen E.; and CemAr M. (2014):

The impact of obesity and insulin resistance on iron and red blood cell parameters: A Single Center, Cross-Sectional Study., Turk J Hematol; 31:61-67.

Amin, K.A. and Nagy M.A. (2009):

Effect of Carnitine and herbal mixture extract on obesity induced by high fat diet in rats. Diabetology\& Metabolic Syndrome, 1:17.

Aronne, L.J. (2001):

Epidemiology, morbidity, and treatment of overweight and obesity . J Clin Psychiatry., 62 (Suppl. 23):13-22.

Bekri, S.; Gual, P.; Anty, R.; Luciani, N.; Dahman, M. and et al. (2006):

Increased adipose tissue expression of hepcidin in severe obesity is independent from diabetes and nash. Gastroenterology, 131:788-796. 
Hanan M. El-Ghandour, Eman M. Ragheb,

Bergmeyer H.U.; Schreiber P. and Wahlefeld A.W. (1978):

Optimization of methods for aspartate and alanine aminotransferase. ClinChem; 24:58-61.

Bogusz, M.J; Tufail, M. and Hassan, H. (2002):

How natural are 'natural herbal remedies'? A Saudi perspective.Adverse Drug React Toxicol. Rev., 21:219-229.

Campos M.S.; Barrionuevo M.; Alferez M.; Gomez-Ayala A.E.; Rodriguez-Matas M.C.; Lopez Aliaga I. and Lisbona F. (1998):

Interactions among iron, calcium, phosphorus and magnesium in the nutritionally iron-deficient rat. Experimental Physiology, 83: $771-781$

Carnethon M.R.; Loria C.M.; Hill J.O. and et al., (2004):

Coronary Artery Risk Development in Young Adults study. Risk factors for the metabolic syndrome: the Coronary Artery Risk Development in Young Adults (CARDIA) study, 1985-2001. Diabetes Care, 27: 2707-2715.

Canbakan, B.;Tahan, V.; Balci, H.;Hatemi, I.;Erer, B.; Ozbay, G.; Sut, N.; Hacibekiroglu, M. ; Imeryuz, N. and Senturk, H. (2008):

Leptin in nonalcoholic fatty liver disease. Ann Hepatol.,7(3):24954.

Cheng H.L.; Bryant C.; Cook R.; O'Connor H.; Rooney K. and Steinbeck K. (2012):

The relationship between obesity and hypoferraemia in adults: a systematic review. Obes Rev.,13:150-161. 


\section{Egyptian J. of Nutrition Vol. XXXIII No. 1 (2018)}

Dacie J.V. and Lewis S.M. (1991):

Practical haematology (7th ed.) (pp 37-85). Edinburgh:ELBS with Churchill Livingstone.

Dambal S.; Indumati. V. and Kumari S. (2011):

Relationship of obesity with micronutrient status, International Journal of Applied Biology and Pharmaceutical Technology., 2(1):280-284.

Fernández-Sánchez A.; Madrigal-Santillán E.; Bautista M.; and et al., (2011):

Inflammation, Oxidative Stress, and Obesity. Int. J. Mol. Sci., 12: 3117-3132.

Fishman. S.M. (2000):

The role of vitamins in prevention and control of anemia. Public Health Nutrition, 3(2): 125-50.

Fridewald, W.T.; Leve R.I. and Fredrickson D.S. (1972);

Estimation of the concentration of low density lipoprtein separated by three different methods. Clin. Chem., 18: 499-502.

Galal, O.M. (2002):

The nutrition transition Egypt: Obesity, Under nutrition and the food consumption context, Public Health Nutrition, 5 (1A): 141 148.

Gandia-Herrero, F.; Escribano, J. and Garcia-Carmona, F. (2010): Structural implications on color, fluorescence, and antiradical activity in betalains. Planta ., 232 (2): 449-460. 
Hanan M. El-Ghandour, Eman M. Ragheb,

García O.; Ronquillo D.; CaamañoMaría d.; Martínez G.; Camacho M.; López V. and Rosado J. (2013):

Zinc, iron and vitamins a, c and e are associated with obesity, inflammation, lipid profile and insulin resistance inmexican school-aged children. Nutrients, 5: 5012-5030.

Garcia-Diaz, D.; Campion, J.; Milagro, F.I. and Martinez, J.A. (2007):

Adiposity dependent apelin gene expression: Relationships with oxidative and inflammation markers. Mol. Cell. Biochem., 305: 87-94.

Garcia-Diaz D.; Lopez-Legarrea P.; Quintero P. and Alfredo M. (2014)

Vitamin C in the Treatment and/or Prevention of Obesity. Journal of Nutritional Science and Vitaminology., 60:367-379.

German, J.B. and Dillard, C.J. (2004):

Saturated fats: what dietary intake? American Journal of Clinical Nutrition.; 80(3):550-559.

Georgiev, V.G.; Weber, J.; Kneschke, E.M.; Denev, P.N.; Bley, T. and Pavlov, A.I. (2010):

Antioxidant activity and phenolic content of betalain extracts from intact plants and hairy root cultures of the red beetroot Beta vulgaris cv. Detroit dark red. Plant Foods for Human Nutrition., 65 (2):105-111. 


\section{Egyptian J. of Nutrition Vol. XXXIII No. 1 (2018)}

Hansen C.M. (1994):

Oral iron supplements. Am Pharm., 34: 66 -71.

Hess, S.Y.; Zimmermann, M.B.; Arnold, M.; Langhans, W. and Hurrell, R.F. (2002).

Iron deficiency anemia reduces thyroid peroxidase activity in rats. J. Nutr.,; 132: 1951-1955.

Kanner J.; Harel S. and Granit R. (2001):

Betalains-a new class of dietary cationized antioxidants. J Agric Food Chem 49: 5178- 5185.

Kapadia, G.J.; Azuine, M.A.; Sridhar, R.; Okuda, Y.; Tsuruta, A.; Ichiishi, E.; Mukainake, T. and et al., (2003):

Chemoprevention of DMBA-induced UV-B promoted, NOR-1induced TPA promoted skin carcinogenesis, and DEN-induced phenobarbital promoted liver tumors in mice by extract of beetroot.Pharmacol. Res., 47(2): 141- 148.

Kazimierczak, R.; Hallmann, E.; Lipowski, J.; Drela, N., and et al., (2014):

Beetroot (Beta vulgaris L.) and naturally fermented beetroot juices from organic and conventional production: metabolomics, antioxidant levels and anti-cancer activity. Journal of the Science of Food and Agriculture.

Keaney J.F.; Larson M.G.; Vasan R.S. and et al. (2003):

Obesity and systemic oxidative stress. Clinical correlates of oxidative stress in the Framingham study. ArteriosclerThrombVascBiol ., 23: 434-439 
Hanan M. El-Ghandour, Eman M. Ragheb,

Khoshnevisan F.; Kimiajar M.; Kalantaree N.; Valaee N. and Shaheedee N. (2004):

Effect of Nutrition education and diet modification in iron depleted preschool children in nurseries in Tehran: a pilot study. Int J VitamNutr Res.,74(4):264-268,.

Kujala, T.S.; Vienola, M.S.; Klika, K.D.; Loponen, J.M. and Pihlaja, K. (2002):

Betalain and phenolic compositions of four beetroot (Beta vulgaris) cultivars. Eur. Food. Res. Technol., 214:505-510.

Liu M.; Shen L.; Liu Y.; Woods S.; Seeley R.; D’Alessio D. and Tos P. (2004):

Obesity induced by a high-fat diet downregulatesapolipoprotein A-IV gene expression in rat hypothalamus. Am $\mathrm{J}$ PhysiolEndocrinolMetab., 287: E366-E370.

Low S.; Chin M.C. and Deurenberg-Yap, M. (2009):

Review on epidemic of obesity. Ann. Acad. Med.Singapore., 38: 57-59.

Manios, Y.; Moschonis, G.; Chrousos, G.P.; Lionis, and et al.(2013):

The double burden of obesity and iron deficiency on children and adolescents in greece: The healthy growth study. J. Hum. Nutr.Diet.,26: 470-478.

Manyanga T.; El-Sayed H.;,TeyeDoku D and Randal J. (2014):

The prevalence of underweight, overweight, obesity and associated risk factors among school-going adolescents in seven African countries. BMC Public Health. , 14:887. 


\section{Egyptian J. of Nutrition Vol. XXXIII No. 1 (2018)}

McArdleMA.; Finucane OM.; Connaughton RM. and et al., (2013):

Mechanisms of obesity induced inflammation and insulin resistance: insights into the emerging role of nutritional strategies. Front Endocrinol (Lausanne)., 4: 52.

McLean E.; Cogswell M.; Egli I.; Wojdyla D. and de Benoist B. (2009):

Worldwide prevalence of anaemia, WHO Vitamin and Mineral Nutrition Information System, 1993-2005. Public Health Nutr., 12 (4): 444 - 454.

Menzie C.M.; Yanoff L.B.; Denkinger B.I.; McHugh T.; Sebring N.G.; Calis K.A. and Yanovski J.A. (2008):

Obesity-related hypoferremia is not explained by differences in reported intake of heme and nonheme iron or intake of dietary factors that can affect iron absorption. J Am Diet Assoc.,108:145-148.

Moretti D.; Zimmermann M.B.; Muthayya S. and et al. (2006):

Extruded rice fortified with micronized ground ferric pyrophosphate reduces iron deficiency in Indian schoolchildren: a doubleblind randomized controlled trial. Am J Clin N-utr., 84: 822-829.

Munoz, M.; Botella-Romero, F.; Gomez-Ramirez, S.; Campos, A. and Garcia-Erce, J.A. (2009):

Iron deficiency and anaemia in bariatric surgical patients: Causes, diagnosis and proper management.Nutr. Hosp., 24:640-654. 
Hanan M. El-Ghandour, Eman M. Ragheb,

National Nutrition Institutes, (2004):

Report on the prevalence of obesity in Egypt.

Ninfali P. and Angelino D. (2013):

Nutritional and functional potential of Beta vulgaris cicla and rubra.Fitoterapia., 89:188-99.

Novelli E.L.; Diniz Y.S.; Galhardi C.M.; Ebaid G.M.; Rodrigues H.G. and et al., (2007) :

Anthropometrical parameters and markers of obesity in rats. Lab Anim. 41(1):111-9.

Pal, R.; Girhepunje, K.; Gevariya, H. and Thirumoorthy, N. (2010). Hepatoprotective activity of Beta vulgaris against $\mathrm{CCl} 4$ induced acute hepatotoxicity in rats. Archives of Applied Science Res., 2(1): 14-18.

Pinhas-Hamiel O.; Newfield R.S.; Koren I.; Agmon A.; Lilos P. and Phillip M. (2003):

Greater prevalence of iron deficiency in overweight and obese children and adolescents. Int J ObesRelatMetabDisord., 27:416418.

Priya N.; Malarvizhi M. and Jothi A. (2013):

Beet root juice on haemoglobin among adolescent girls , Journal of Nursing and Health Science., 2(1): 09-13.

Qureshi E..; Shabana A. and Fareeha A. (2006):

Effect of Overweight and Obesity on Liver Function in a Sample From Pakistani Population. Pakistan J. Zool., 38(1):49-54. 


\section{Egyptian J. of Nutrition Vol. XXXIII No. 1 (2018)}

Reddy, M.K.; Alexander-Lindo, R.L. and Nair, M.G. (2005):

Relative inhibition of lipid peroxidation, cyclooxygenase enzymes, and human tumor cell proliferation by natural food colors. Journal of Agricultural and Food Chemistry., 53 (23):9268-9273.

Reeves, R.G.; Nielsen, F.H. and Fahey, G.C. (1993):

AIN-93 Purified Diets for Laboratory Rodents" .J. Nutr.,123(1):1939-1951.

Richmond, N. (1973):

Colorimetric determination of total cholesterol and high density lipoprotein cholesterol (HDL-c). Clin. Chem., 19: 1350-1356.

Rotondi M.; Leporati P.; La Manna A.; Pirali B.; Mondello T.; Fonte R.; Magri F. and Chiovato L. (2009):

Raised serum TSH levels with morbid obesity: is it enough to diagnose subclinical hypothyroidism? Eur J Endocrinol.,160:403408.

Sadeek, E. (2011):

Protective effect of fresh Juice from red beetroot (Beta vulgaris L.) and radish (Raphanussativus L.) against carbon tetrachloride - induced hepatotoxicity in rat models ., African J. Biol. Sci., 7(1): 69-84 .

Sanad, M.; Osman, M. and Gharib, A. (2011):

Obesity modulate serum hepcidin and treatment outcome of iron deficiency anemia in 
Hanan M. El-Ghandour, Eman M. Ragheb,

Siegenberg D.; Baynes R.D.; Bothwell T.H.; Macfarlane B.J. et al., (1991):

Ascorbic acid prevents the dose dependent inhibitory effects of polyphenols and phytates on nonheme-iron absorption. Am J ClinNutr, 53: 537-541,.

Slavov A.; Karagyozov V.; Denev P.; Kratchanova M. and Kratchanov C. (2013):

Antioxidant Activity of Red Beet Juices Obtained after Microwave and Thermal Pretreatments, Czech J. Food Sci., 31( 2): 139147.

Soliman, G.; Mahfouz, M. and Emara, I. (2010).

Effect of Different Types of Oral Iron Therapy Used for the Treatment of Iron Deficiency Anemia and Their Effects on Some Hormones and Minerals in Anemic Rats., Journal of American Science, 6(6):109-118.

SPSS (1986):

Statistical package for social science, version 19. SPSS Inc., II. U.S.A.

Tesoriere, L.; Butera, D.; D’Arpa, D.; Di Gaudio, F.; Allegra, M.; Gentile, C. and Livrea, M.A. (2003):

Increased resistance to oxidation of betalain-enriched human low-density lipoproteins. Free Radical Research., 37 (6): 689696.

Tussing-Humphreys, L.M.; Liang, H.; Nemeth, E.; Freels, S. and Braunschweig, C.A.(2009):

Excess adiposity, inflammation, and iron-deficiency in female adolescents. J. Am. Diet. Assoc., 109: 297-302. 


\section{Egyptian J. of Nutrition Vol. XXXIII No. 1 (2018)}

Vigueras-Villaseñor R.M.; Rojas-Castañeda J.C.; ChávezSaldaña M.; Gutiérrez-Pérez O. and et al., (2011):

Alterations in the spermatic function generated by obesity in rats. ActaHistochem.,113(2):214-20.

Vulić, J.J.; Ćebović, T.N.; Čanadanović-Brunet, J.M.; Ćetković, G.S.; Čanadanović, V.M.; Djilas, S.M. and TumbasŠaponjac, V.T.(2014):

In vivo and in vitro antioxidant effects of beetroot pomace extracts. J. Funct. Foods., 6:168-175.

Wahlefeld A.W. (1974):

Triglycerides determination after enzymatic hydrolysis H.U. Bergmeyer (Ed.), Methods of Enzymatic Analysis, Academic Press, New York (1974), pp. 1831-1838

Weissman N.; Schoenbach E.B. and Armestead E.B. (1950):

J.biol. chem., 187:153.Cited in the Panphlet of Stanbio Laboratory, Boerne, Texas, USA.

WHO, (2012):

Obesity and overweight. Fact sheet No. 311.

WHO, (2014):

Obesity and overweight, Geneva: World Health Organization.

Wilson PW.; D'Agostino RB.; Parise H. and et al., (2005) :

Metabolic syndrome as a precursor of cardiovascular disease and type 2 diabetes mellitus . Circulation.,112: 3066-3072. 
Hanan M. El-Ghandour, Eman M. Ragheb,

WinzellM. and AhrénB.o. (2004):

The High-Fat Diet-Fed Mouse A Model for Studying

Mechanisms and Treatment of ImpairePd Glucose Tolerance

and Type 2 Diabetes, Diabetes, 53(Supplement 3):S215-S219.

Wolford S.T.; Schroer R. A.; Gohs F.X.; Gallo P. P.; Brodeck M., H.; Falk B. and Ruhren R.J. (1986):

Reference range data base for serum chemistry and hematology values in laboratory animals. J Toxicol Environ Health., 18(2):161-88.

Wootton-Beard, P. and Ryan, L. (2011):

A beetroot juice shot is a significant and convenient source of bioaccessible antioxidants. J. Funct. Foods., 3:329-334.

Xiong, Y.; Shen L.; Liu K.J.; Tso P.; Xiong Y.; Wang G.; Woods S.C. and Liu K. (2005):

Anti-obesity and anti hyperglycemic effects of ginsenoside Rb1in rats. Diabetes., 59: 2505-2512.

Yanoff L.B.; Menzie C.M.; Denkinger B.; Sebring N.G.; McHugh T.; Remaley A.T. and Yanovski J.A. (2007):

Inflammation and iron deficiency in the hypoferremia of obesity. Int J Obes (Lond)., 31:1412-1419.

Zielińska-Przyjemska, M.; Olejnik, A.; Dobrowolska-Zachwieja, A. and Grajek, W. (2009):

In vitro effects of beetroot juice and chips on oxidative metabolism and apoptosis in neutrophils from obese individuals. Phytophera Res., 23: 49-55. 
Egyptian J. of Nutrition Vol. XXXIII No. 1 (2018)

تأثير عصير البنجر الطازج علي حالة وزن الجسم في الفئران البدينة

والمصابة بالأنيميا

حنان محمد الغندور - إيمان محمود راغب الآبيا

مركز البحوث الزراعيه ــ المركز الإقليمي للأغذيه والأعلاف

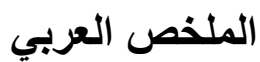

تهدف هذه الدراسة الي معرفة تأثير (1مللي ، 2 مللي/كجم من وزن الجسم) من عصير

البنجر الاحمر الطازج في تحسين فقر الدم وتأثيره على وزن الجسم النهائى في الفئران البدينة

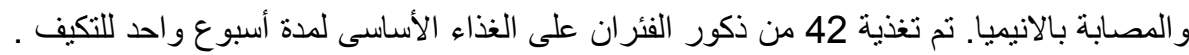

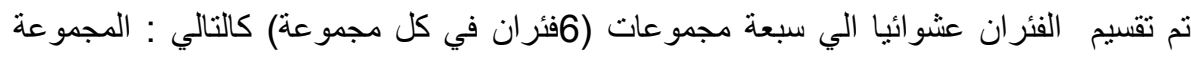
الاولي تتغذي علي الغذاء الاساسي فقط (مجموعة ضابطة سالبة)، بينما تم تغذية 18 من الفئران فى المجموعات (2 إلى 4) علي وجبة عالية في محتواها من الدهون لمدة اربع اسابيع لاحداث

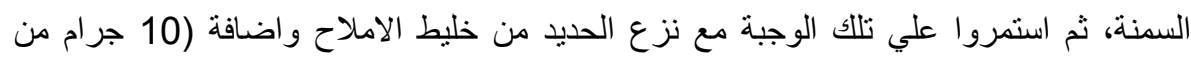

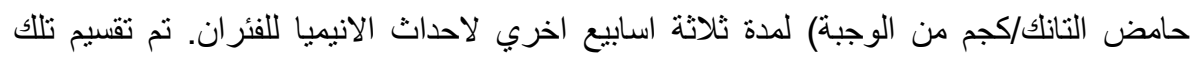

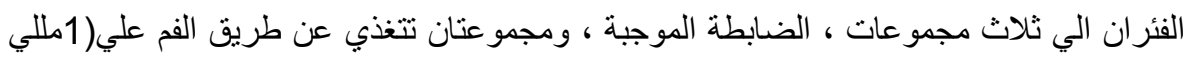

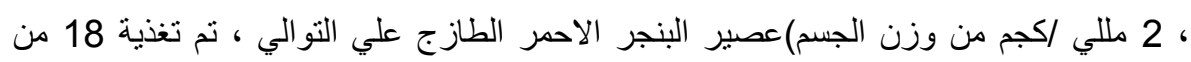
الفئران فى المجموعات ( 5 إلى7) علي الوجبة الأساسية مع نزع الحديد من خليط الاملاح

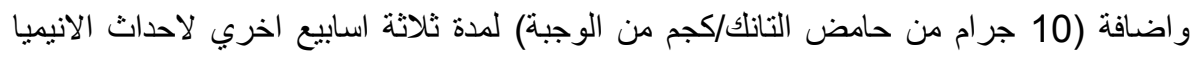

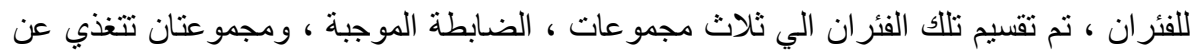

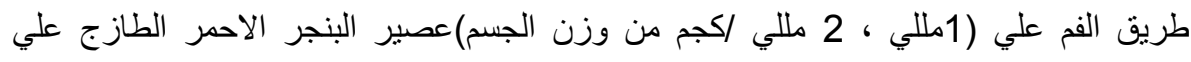

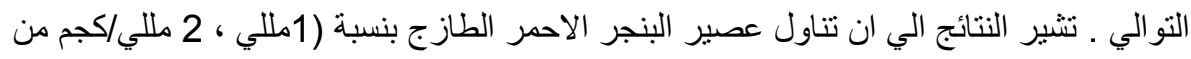

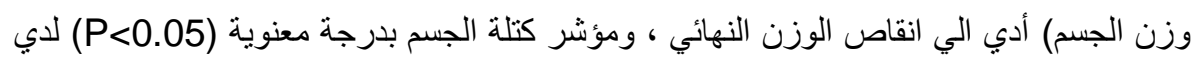

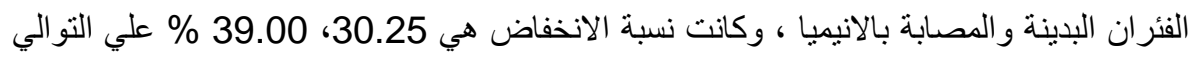

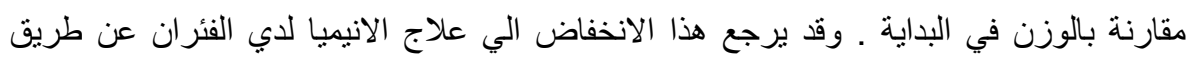

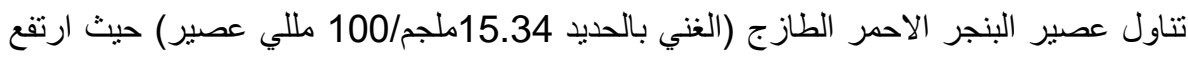
عدد كرات الدم الحمراء ونسبة الهيموجلوبين ونركيز الهيماتوكريت ونسبة الحديد الكلي بدرجة الهية معنوية (P>0.05) ، كما تم تحسين صورة الدهون وتحسين وظائف الكلي والكبد مقارنة 


\section{Hanan M. El-Ghandour, Eman M. Ragheb,}

بالمجموعة الضابطة الموجبة . علاوة علي ذللك فقد انخفض مستوي هرمون اللبتن بدرجة معنوية (P>0.05) لدي الفئران التي تناولت الجرعات المختلفة من العصير مقارنة بالمجموعة

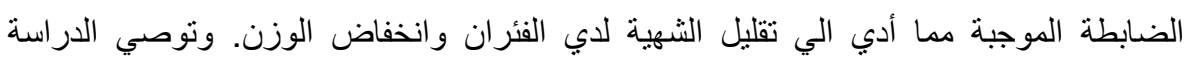

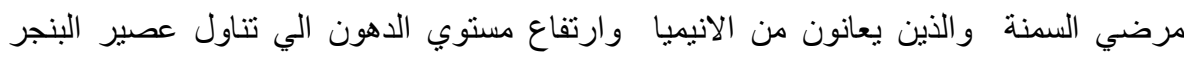
الاحمر الطازج 